\title{
Biomass Yield of Selected Herbaceous and Woody Industrial Crops across Marginal Agricultural Sites with Shallow Soil
}

\author{
Jana Reinhardt ${ }^{\dagger}$, Pia Hilgert ${ }^{\dagger}$ and Moritz von Cossel *(D) \\ Biobased Resources in the Bioeconomy (340b), Institute of Crop Science, University of Hohenheim, \\ 70599 Stuttgart, Germany; jana.reinhardt93@gmail.com (J.R.); pia.hilgert@uni-hohenheim.de (P.H.) \\ * Correspondence: moritz.cossel@uni-hohenheim.de \\ † Authors contributed equally to the work.
}

check for updates

Citation: Reinhardt, J.; Hilgert, P.; von Cossel, M. Biomass Yield of Selected Herbaceous and Woody Industrial Crops across Marginal Agricultural Sites with Shallow Soil. Agronomy 2021, 11, 1296. https: / / doi.org/10.3390/agronomy11071296

Academic Editor: Jerome H. Cherney

Received: 2 June 2021

Accepted: 24 June 2021

Published: 26 June 2021

Publisher's Note: MDPI stays neutral with regard to jurisdictional claims in published maps and institutional affiliations.

Copyright: (c) 2021 by the authors. Licensee MDPI, Basel, Switzerland. This article is an open access article distributed under the terms and conditions of the Creative Commons Attribution (CC BY) license (https:/ / creativecommons.org/licenses/by/ $4.0 /)$.

\begin{abstract}
Agricultural land in Europe is affected by low rooting depth (LRD) on 27.9 Mha. This marginal agricultural land can potentially be used to grow industrial crops without directly threatening food security or biodiversity conservation. However, little is known about the yield performance of industrial crops at LRD conditions. This study therefore compiles and discusses the meaningful data available in scientific literature. Twelve relevant industrial crops were identified for Europe. Currently, robust information on good growth suitability for LRD conditions is available for only one industrial crop, namely reed canary grass (RCG). Because this information was taken from field trial results from a single site, it remains unclear what role other growing conditions such as soil quality and climate play on both the yield level and the biomass quality of RCG under LRD conditions. These uncertainties about the quantitative as well as qualitative performance of industrial crop cultivation on marginal agricultural land characterized by LRD represent a major agronomic knowledge gap. Here, more knowledge needs to be compiled through both expanded crop science activities and improved international information exchange to make more optimal use of the large LRD areas available for the transition to a bioeconomy.
\end{abstract}

Keywords: annual crops; low rooting depth; marginal land; perennial crops; shallow rooting depth; unfavorable growth conditions

\section{Introduction}

More than $47 \%$ of agricultural land in Europe is characterized by low rooting depth (LRD) [1]. This so called marginal agricultural land is deemed available for the cultivation of herbaceous and woody industrial crops for various biomass utilization pathways. Availability is based on the assumption that the cultivation of herbaceous and woody industrial crops on marginal agricultural land does not conflict with food production or nature conservation and can thus potentially contribute to a social-ecologically more sustainable utilization of these areas [2,3]. However, methods for regional assessment of the actual utilization status of European marginal land affected by LRD and other constraints are still under development [4]. This is necessary because not all of this land is actually abandoned and not used for agricultural production. In exceptional cases, such unproductive agricultural areas are in fact used for the cultivation of food crops through irrigation, which can be determined, for example, through satellite imagery [4]. On such land, there would therefore be a certain conflict of use between the cultivation of industrial and food crops, which must be taken into account when determining the actual available area of marginal agricultural land with LRD conditions. Nevertheless, the utilization of marginal agricultural land affected by LRD represents a tremendous potential for the production of biomass [5] that is urgently required to successfully and promptly manage the transition to a bioeconomy [6,7].

A well-developed and deep root system, however, is a key factor for crops, including herbaceous and woody industrial crops, to adapt to environmental conditions and for good 
growth and high yield levels [8]. It facilitates access to nutrients and water and increases the ability of the plant to compete with other species [9]. Roots in the upper soil layers, in particular, serve for the efficient use of mineral nutrients. Deep roots, on the other hand, contribute to a better water supply, especially under drought stress [10]. Where there are no barriers to root growth, most crop roots extend to depths of 60 to $120 \mathrm{~cm}$ [11]. The maximum root depth of winter wheat in a trial in Austria was 150-160 cm [10]. The maximum root depth of wheat is generally between $80-180 \mathrm{~cm}$ [12]. Therefore, a LRD means a limited availability of nutrients and water and thus an impairment of plant growth $[8,13]$. This also restricts soil cultivation [13]. Under LRD conditions, the rooting depth is generally limited by coherent hard rock or a dense soil layer. Following Rossiter et al. [11], sites are described as marginal due to their low LRD with a soil depth of $\leq 35 \mathrm{~cm}$. This limit value is chosen very low, because a rooting depth of $35 \mathrm{~cm}$ means a very strong restriction of plant growth [11]. Hence, for this work the limit value of Mueller et al. [14] will be used; it gives a limit of $<50 \mathrm{~cm}$ for flat and very flat soils. If a site is described as having shallow soil, it can also be classified as marginal due to LRD.

Consequently, among many socioeconomic challenges [15-19], the success of cultivating herbaceous and woody industrial crops on marginal agricultural land with LRD conditions is critical, with biomass yield being one of the most important components [20,21] that is currently being investigated, for example, at University of Hohenheim (Figure 1).

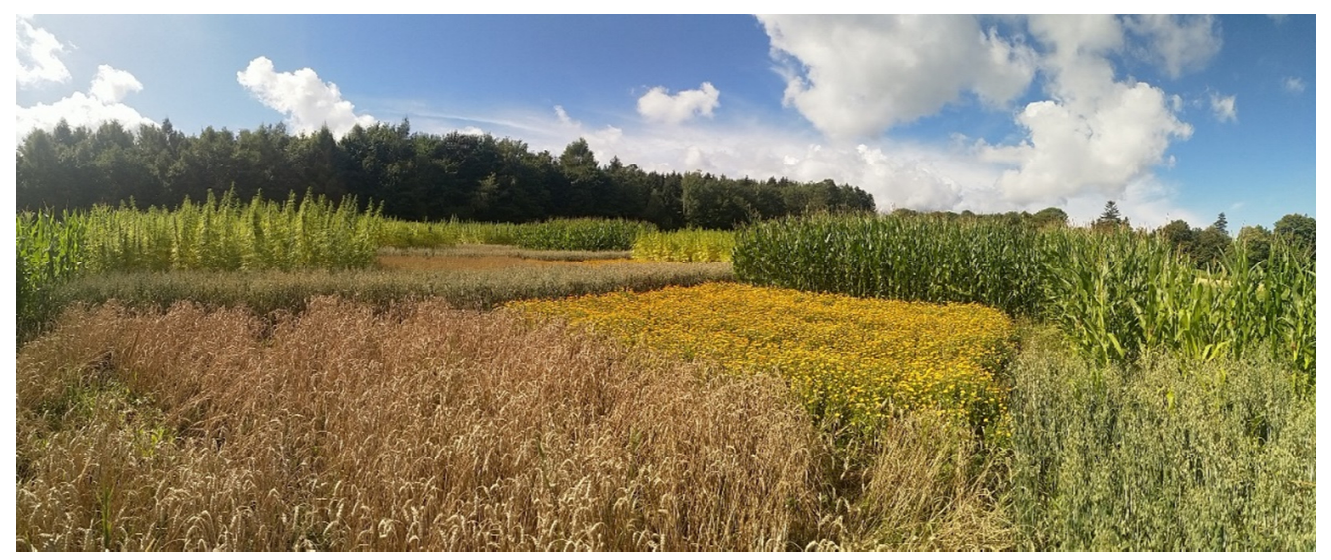

Figure 1. Impression of an ongoing field trial with herbaceous industrial crops hemp, camelina, and calendula in comparison with common food/feed crops maize and winter wheat under low rooting depth conditions (0.2-0.4 m rootable top soil above hard rock) at an experimental station of University of Hohenheim in southwest Germany. The photo was taken in summer 2020.

As little as is known about the performance of herbaceous and woody industrial crops on marginal agricultural land characterized by LRD [1,22], it can already be seen that there are very different specialists among the known herbaceous and woody industrial crops [23], which means that suitable biomass production systems could be developed for almost any type of marginal agricultural land [2]. The relevance of agricultural marginality constraints can be expressed by the size of agricultural land affected. The total area of available European marginal agricultural land with shallow soil accounts for about 27.9 Mha [1]. Since there is still much uncertainty about the link between LRD on marginal agricultural land and biomass yield of herbaceous and woody industrial crops [1,24], Gerwin et al. [1] claim that this must be investigated more in detail in the future. Therefore, this study focuses on the following main research question: How do herbaceous and woody industrial crops perform in terms of biomass yield on marginal agricultural land with shallow soil?

\section{Material and Methods}

In this study, the biomass yield of herbaceous and woody industrial crops on favorable agricultural land (favorable climate and fertile soils) across the northern hemisphere $[25,26]$ 
was used as reference for the herbaceous and woody industrial crops' yield performance on marginal agricultural land characterized by LRD. This was intended to enable first insights into the future potential of biomass production on that specific type of marginal agricultural land.

\subsection{Identification of Most Relevant Herbaceous and Woody Industrial Crops in Europe}

Only those herbaceous and woody industrial crops were selected that were involved at least four times in one of the EU projects that started or ended in the period 1 January 2014 to 6 December 2019. Using the Community Research and Development Information Service (CORDIS) [27], 24 EU projects were found and considered for this purpose: Becool, BIO4A, COMETHA, COSMOS, DENDROMASS 4EUROPE, EUPOBIOREF, FIBRA, FIRST2RUN, FORBIO, GRACE, GRASSMARGINS, LIBBIO, AGIC, Mediopuntia, MULTIBIOPRO, Multihemp, OPTIMA, OPTIMISC, PANACEA, PHYSIO-POP, SEEMLA, SUNLIBB, SWEET fuel, and WATBIO (Table A1). In this way, twelve herbaceous and woody industrial crops were found relevant (Table A2), which is mostly in line with the crop selections in other studies [2,23]. These crops were examined in more detail in the remainder of this study, i.e., the literature review described in the following sections.

\subsection{Literature Search}

To obtain information about the yigeld performance of the most relevant herbaceous and woody industrial crops in Europe under LRD conditions, an extensive literature search in the database Scopus ${ }^{\circledR}$ (Elsevier BV, Amsterdam, The Netherlands) was carried out. To make the search queries in Scopus ${ }^{\circledR}$ as precise as possible, the advanced search function was used which enables a complex search order by means of field codes and Boolean operators [28].

First, the database was searched for papers in which the plant name appears in the title, abstract, or keywords. Keywords were selected for each plant as follows:

- camelina: Camelina;

- cardoon: Cynara cardunculus, artichoke thistle,

- cardoon; crambe: crambe;

- $\quad$ cup plant: Silphium perfoliatum, cup plant;

- giant reed: Arundo donax, giant reed;

- hemp: Cannabis sativa, hemp;

- Miscanthus: Miscanthus;

- poplar: Populus, poplar;

- $\quad$ reed canary grass: Phalaris arundinacea, reed canary grass;

- $\quad$ sorghum: Sorghum bicolor;

- $\quad$ switchgrass: Panicum virgatum, switchgrass;

- willow: Salix, willow.

Then, articles with terms such as "model", "gis", or "gene" were removed as they would most likely not be original articles with field trial results. Afterward, the results were screened for the marginality constraint LRD. The results were then further selected for those articles including terms such as "biomass", "yield", or "harvest". Of the studies found, those that met certain requirements were then selected, such as the existence of field trials, and information on yield, time, and location of the experiment. Weather conditions and soil properties also had to be adequately specified. Studies were excluded if their sites had high salinity, heavy metal contamination, or acidic soils. The climate of the sites found in the studies needed to be similar to one of the main European agroecological zones (Mediterranean, Atlantic, Continental/Boreal) and located in the northern hemisphere, if the study was not from Europe. Special selection criteria were also chosen for willow and sorghum-only field trials with short rotation coppice for willow and no grain use varieties for sorghum were taken into account.

\subsection{Suitability Ranking of the Identified Crops}

Based on the yield data and discussion in further literature, a classification of the cultivation suitability according to a classification of Ramirez-Almeyda et al. [5] was conducted. 
If no sites were found that met (or properly describe) the threshold for LRD (soil depth of $\leq 50 \mathrm{~cm}$ ), the classification was based only on further literature. The suitability values are then given in brackets. The suitability values denote as follows: $4=$ "very good", much higher yields than average yields on favored sites; $3=$ "good", yields approximately equivalent to the average yields on favored sites; 2 = "average", lower yield compared to average yields on favored sites; and $1=$ "low" much lower yields than average yields on favorable sites. If the plant is classified as " $0=$ unsuitable", it cannot grow on sites with LRD.

\section{Results and Discussion}

According to the methodology described above, seven sites were found in seven papers that comply with the threshold values for LRD as defined by Rossiter et al. [11] (Figure 2, Table 1). Further details on the field trials of the identified references are provided in the annex (Tables A3 and A4). Some sites and their respective tests, which also meet the criteria for LRD, could not be identified using the methodology described. The reason for this was that in order to classify a site into marginal, certain information about the site was required. However, this information is often missing in papers.

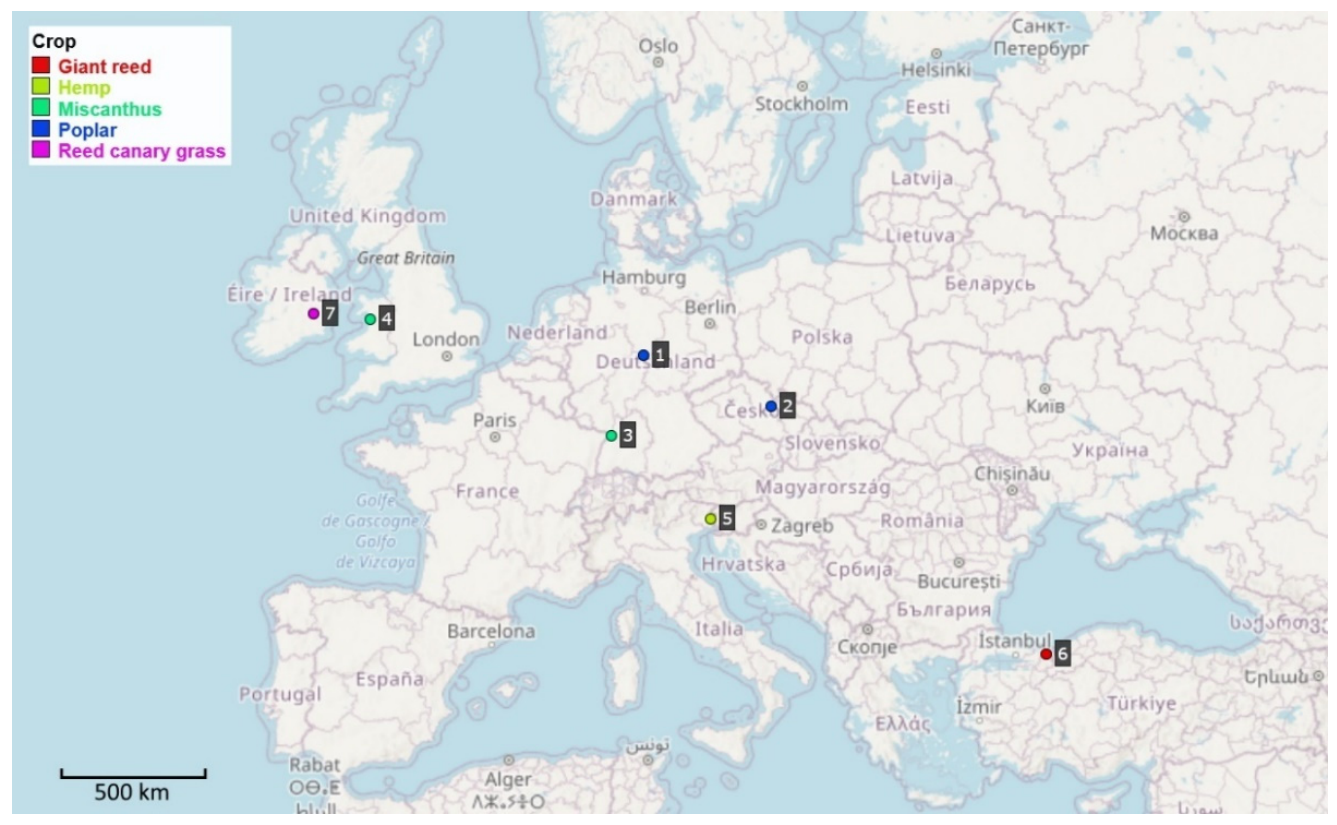

Figure 2. Overview of the field trial locations of the studies identified in the literature review. Colors indicate the respective industrial crops investigated in the field trials. The numbers (1-7) denote for the site numbers as presented in Table 1. Map created using GPSvisualizer (www.gpsvisualizer.com).

Table 1. Overview of studies and locations identified in the literature search.

\begin{tabular}{|c|c|c|c|c|c|c|c|}
\hline \multirow[b]{2}{*}{ Site Number } & \multirow[b]{2}{*}{ Crop } & \multirow[b]{2}{*}{ Country } & \multirow[b]{2}{*}{ City } & \multicolumn{4}{|c|}{ Constraints Other Than LRD } \\
\hline & & & & m a.s.l. & UST & Steep Slope & Reference \\
\hline 1 & Poplar & Germany & Göttingen & 206 & & & [29] \\
\hline 2 & Poplar & Czech Republic & Domanínek & 578 & & 1 & [30] \\
\hline 3 & Miscanthus & Germany & Durmersheim & 118 & $1 \mathrm{~S}$ & & [31] \\
\hline 4 & Miscanthus & Great Britain & Aberystwyth & 39 & $1 \mathrm{St}$ & & [32] \\
\hline 5 & Hemp & Italy & Udine & 109 & & & [33] \\
\hline 6 & Giant reed & Turkey & Sakarya & 244 & & & [34] \\
\hline 7 & Reed canary grass & Ireland & Carlow & 15 & 1S St & & [35] \\
\hline
\end{tabular}




\subsection{Field Trial Observations}

In the following sections, the cultivation suitability of the twelve identified herbaceous and woody industrial crops under LRD conditions is discussed. Each crop is only considered individually, which means that no further statements can yet be made on their implementability in existing agricultural systems. As already mentioned in the introduction, this is an overview of crop-specific suitability for LRD conditions. This is an important first step for the extensive effort needed to implement a bio-based economy that requires further follow-up research, such as the integration to existing agricultural systems, which is justified in more detail at the end of the discussion. Here, all yield figures are listed as yield per year (biomass, stalk, oil, grain, and ethanol yields, respectively), and only the aboveground biomass of the crops is considered. All crops for which field trial data were found in the literature were cultivated in single cropping. This means that no intercropping approaches were considered here, which is not to say that this is fundamentally irrelevant. Intercropping often helps to make better use of limited nutrient supply of cultivation-limited sites, such as LRD dominated marginal agricultural land [36]. However, so far only information on food and forage crops can be found, not on industrial herbaceous and woody crops.

\subsubsection{Giant Reed}

About $50 \%$ of all dry matter (DM) yield data of giant reed are in the range of $25-40 \mathrm{Mg} \mathrm{ha}^{-1}$ [37]. Under favorable growing conditions, giant reed shows very high DM yields of $33.8 \mathrm{Mg} \mathrm{ha}^{-1}$ [38] to $37.7 \mathrm{Mg} \mathrm{ha}^{-1}$ [39]. This is in line with Pilu et al. [40] who report DM yields of $36-55 \mathrm{Mg} \mathrm{ha}^{-1}$.

One experiment was found for giant reed cultivation on marginal agricultural land with LRD (Table 2). This experiment was carried out on a site that is marginal due to its eroded flat soil profile. It is located in Sakarya, Turkey. In Ozdemir et al. [34], unfortunately, no information is given on the exact rooting depth of the Sakarya site. However, the experiment shows that giant reed produces a yield of $8.3 \mathrm{Mg} \mathrm{ha}^{-1} \mathrm{DM}$ on marginal agricultural land with this factor without fertilization and irrigation. Compared to favorable sites, this is much lower $[39,40]$. In a further test variant on this site, fertilization with poultry slaughter sludge was applied, which led to a higher yield $\left(16.5 \mathrm{Mg} \mathrm{ha}^{-1} \mathrm{DM}\right.$ in the second-third year of cultivation at the highest fertilization level $200 \mathrm{~N} \mathrm{~kg} \mathrm{ha}^{-1}$ ). In comparison to a fertile location, however, this yield is also lower. To develop a good rhizome system a deep soil is required. On a soil with a low root depth the establishment of giant reed is therefore limited, as is the agricultural cultivation of giant reed [13]. A location with a root depth of $<35 \mathrm{~cm}$ is challenging and according to Parenti et al. [13] unsuitable for the cultivation of giant reed, while Von Cossel et al. [23] consider this kind of location slightly suitable for cultivation. A location with a root depth of $35-80 \mathrm{~cm}$ has a medium suitability for cultivation [23]. The test results of Ozdemir et al. [34] confirm the low suitability of giant reed for cultivation on sites with LRD.

\subsubsection{Hemp}

On favorable sites, fiber hemp achieves a stem yield of $10 \mathrm{Mg} \mathrm{ha}^{-1} \mathrm{DM}$ [41]. Struik et al. [42] investigated five different varieties of hemp grown for fiber on three favored sites in Europe (Italy, United Kingdom, and the Netherlands) over three years with different fertilization and plant density variants. A maximum aboveground biomass yield of $22.5 \mathrm{Mg} \mathrm{ha}{ }^{-1} \mathrm{DM}$ and a stalk yield of $18.5 \mathrm{Mg} \mathrm{ha}^{-1} \mathrm{DM}$ were achieved. The average aboveground biomass DM yield over all locations, years, varieties, and trial variants was $14 \mathrm{Mg} \mathrm{ha}^{-1}$ and the stem DM yield $11 \mathrm{Mg} \mathrm{ha}^{-1}$ [42]. In addition, on a sandy loamy soil in Foulum, Denmark, an aboveground biomass DM yield of $13-15 \mathrm{Mg} \mathrm{ha}^{-1}$ was achieved [43].

One site was found that meets the criteria for this agricultural marginality constraint (Tables 1 and 2). The site in Udine (Italy) has a rooting depth of $50 \mathrm{~cm}$ and achieved a grain yield of $0.55 \mathrm{Mg} \mathrm{ha}^{-1}$ and an oil yield of $0.11 \mathrm{Mg} \mathrm{ha}^{-1}$ [33]. Eight different monoecious varieties were grown there. The average yield of $6.1 \mathrm{Mg} \mathrm{ha}^{-1} \mathrm{DM}$ (Table 2) was lower than 
the average yield of $11 \mathrm{Mg} \mathrm{ha}^{-1} \mathrm{DM}$ on sites described by Struik et al. [42]. The highest stalk yield in Udine was achieved with the Futura variety; it was $8.3 \mathrm{Mg} \mathrm{ha}^{-1} \mathrm{DM}$. This was also below the yield of Futura reported by Struik et al. [42]. In addition, the thousand-grain mass on Udine was $7.6 \mathrm{~g}$, which is significantly less than the stated thousand-grain mass on favored sites (17-23 g) [41]. The plants reached an average height of $208 \mathrm{~cm}$, which is in the optimal range for industrial processing of the fibers [41]. In a field test of Amaducci et al. [44] in Cadriano, Italy, 50\% of the root biomass was found in the upper $50 \mathrm{~cm}$ in a deep soil. The root length density was highest in the upper $10 \mathrm{~cm}$ of the soil. Hemp can root to a depth of 2-2.5 m, especially when it grows in dry environments [41,44]. It is likely that hemp yields are reduced on flat soils because it has a poorly developed root system compared to other economically important plants [41]. This is in line with Von Cossel et al. [23], who found that hemp has a low suitability for cultivation in soils with a depth of $35-80 \mathrm{~cm}$ and is unsuitable for soils with a depth less than $35 \mathrm{~cm}$. However, the observations from Udine indicate that hemp is moderately suitable for cultivation when the soil depth is $50 \mathrm{~cm}$, but the choice of the most suitable variety is crucial for this.

Table 2. Annual stalk and biomass yields of monoecious giant reed (Arundo donax L.), hemp (Cannabis sativa L.), Miscanthus (Miscanthus x giganteus Greef et Deuter), poplar (Populus L.), and reed canary grass (Phalaris arundinacea L.) on marginal agricultural land characterized by low rooting depth (LRD).

\begin{tabular}{|c|c|c|c|c|c|}
\hline Site Number & Crop & $\begin{array}{c}\text { Year of Cultivation (Poplar: Age } \\
\text { of Trunk) }\end{array}$ & $\begin{array}{l}\text { Dry Matter Stem } \\
\left.\text { Yield [Mg ha }{ }^{-1}\right]\end{array}$ & $\begin{array}{l}\text { Dry Matter Yield } \\
{\left[\mathrm{Mg} \mathrm{ha}^{-1}\right]}\end{array}$ & Source \\
\hline 1 & Poplar & 3 & & 0.1 & [29] \\
\hline 2 & Poplar & 7 & & 11.7 & [30] \\
\hline 3 & Miscanthus & 4 & & 8.9 & [31] \\
\hline 4 & Miscanthus & 4 & & 16 & [32] \\
\hline 5 & Hemp & & 6.1 & & [33] \\
\hline 6 & Giant reed & $2-3$ & & 8.3 & [34] \\
\hline 7 & Reed canary grass & $2-3$ & & 13 & [35] \\
\hline
\end{tabular}

\subsubsection{Miscanthus}

It was found that $50 \%$ of all yield data of Miscanthus on favored sites are in the range of 13-28 Mg ha ${ }^{-1} \mathrm{DM}$ [37]. With irrigation, yields of over $30 \mathrm{Mg} \mathrm{ha}^{-1} \mathrm{DM}$ can be achieved on sites in Southern Europe (average temperatures of $15.4{ }^{\circ} \mathrm{C}$ ) [45]. In Central and Northern Europe (from Austria to Denmark), where global irradiation and average temperatures are lower $\left(7.3-8.0^{\circ} \mathrm{C}\right)$, yields without irrigation are typically $10-25 \mathrm{Mg}^{-1} \mathrm{DM}$ [45]. In a long-term test of Angelini et al. [39] without irrigation on a favored site near Pisa, the average yield over the 2 nd-12th year of cultivation was $28.7 \mathrm{Mg} \mathrm{ha}^{-1} \mathrm{DM}$. As with Amaducci et al. [46], the yield of the first year of cultivation of this experiment was much lower than in the following years. From the first to the second year the yield increases, in the 3rd-8th year the highest yields are achieved and from the 9th-12th year the yield decreases [39]. The complete establishment of a Miscanthus population takes three to five years [45]. Under optimal location conditions, the full yield potential is achieved after three years, under suboptimal conditions only after five years [47].

Two sites were found that fulfill the criteria of the agricultural marginality constraint LRD (Table 2). The Durmersheim site also fulfilled the criterion [11] for unfavorably high soil content of sand (UST_S) and at the Aberystwyth site, the criterion [11] for stoniness (UST_St) in the topsoil was fulfilled. Miscanthus achieved a yield of $8.9 \mathrm{Mg} \mathrm{ha}^{-1} \mathrm{DM}$ in the fourth year of cultivation in Durmersheim. This is less than on favorable sites in Central and Northern Europe [45]. The summer of the fourth year of cultivation on this site was exceptionally dry. In addition, the two agricultural marginality constraints, UST-S and LRD, have a negative influence on each other [48]. Sandy soils are generally characterized by low fertility, high nutrient leaching, and low water retention capacity. A low soil depth increases these effects, as the volume of water storage in the soil is limited [48]. This could explain the positive effect of fertilization on this site; the stated yield is from a trial 
variant with $50 \mathrm{~kg} \mathrm{~N} \mathrm{ha}^{-1}$, another variant with $100 \mathrm{~kg} \mathrm{~N} \mathrm{ha}^{-1}$ yielded $13.7 \mathrm{Mg} \mathrm{ha}^{-1}$ DM, which is in the lower stated yield range in Central and Northern Europe [31]. The Aberystwyth site has a rooting depth of 30-50 cm. In the fourth year of cultivation the yield of Miscanthus in Aberystwyth was $16 \mathrm{Mg} \mathrm{ha}^{-1} \mathrm{DM}$. This yield corresponds to the yield range in Northern Europe [49]. This site has high rock content (35\%) in addition to the shallow depth. These two agricultural marginality constraints create a negative synergy, since a high stone content further reduces the effective soil volume for rooting, water storage, and nutrient supply in a shallow soil [48]. Following Von Cossel et al. [23], the cultivation of Miscanthus is unsuitable on sites with soil depths below $35 \mathrm{~cm}$, mediocre on soils that are 35-80 cm deep, and good at 80-120 cm. Findings in Ramirez-Almeyda et al. [5] slightly deviate from this classification; at a soil depth of $40-80 \mathrm{~cm}$ the suitability for cultivation of Miscanthus is low, at $80-120 \mathrm{~cm}$ it is average, and similar to Von Cossel et al. [23], it is unsuitable for a depth of less than $40 \mathrm{~cm}$. According to Ferrarini et al. [50], Miscanthus has a deep fine root system on profound soils. Although Miscanthus produces lower yields on shallow soils than on deep soils [51], these are still comparable with yields on favored sites (rather lower half of the yield range), provided there is sufficient water supply and fertilization. For this reason, a medium suitability for cultivation on sites with LRD can be assumed for Miscanthus.

\subsubsection{Poplar}

In a systematic literature search and meta-analysis on poplar yields [37], it was found that $50 \%$ of all yield data are in the range $7-10 \mathrm{Mg} \mathrm{ha}^{-1} \mathrm{DM}$. Berendonk et al. [52] indicate that a yield of $8-12 \mathrm{Mg} \mathrm{ha}^{-1} \mathrm{DM}$ can be expected for short rotation plantations. On a favorable location in Mira in Northern Italy, a yield of $20 \mathrm{Mg} \mathrm{ha}^{-1} \mathrm{DM}$ in the second rotation and $15 \mathrm{Mg} \mathrm{ha}^{-1} \mathrm{DM}$ in the first rotation was achieved [53].

For poplar cultivation under LRD conditions, two studies from Göttingen and Domanínek were found (Table 2). The soil depth of the Göttingen site is $20-50 \mathrm{~cm}$. The poplar hybrids Max 1 (Populus nigra $\times$ P. maximowiczii) and H275 (Populus trichocarpa $\times$ P. maximowiczii) were cultivated on this site, which achieved a very low average yield of $0.1 \mathrm{Mg} \mathrm{ha}^{-1} \mathrm{DM}$. Furthermore, a survival rate of $25 \%$ for $\mathrm{H} 275$ and $60 \%$ for Max 1 was found. The experiment shows that soils with LRD can strongly restrict the growth of the poplar hybrids studied [29]. At the Domanínek site, Populus nigra $\times$ P. maximowiczii achieved a yield of $11.7 \mathrm{Mg} \mathrm{ha}^{-1} \mathrm{DM}$ in the second rotation (which lasted seven years), which is much higher than at the Göttingen site, and also higher than the yields stated in Berendonk et al. [52]. This site has a soil depth of $30-50 \mathrm{~cm}$ and additionally a strongly sandy loam. A survival rate of $70 \%$ was determined [30].

The division into the classification system proposed by Ramirez-Almeyda [5] states that the cultivation of poplar is unsuitable on sites with soil depths of $<40 \mathrm{~cm}$, low at $40-80 \mathrm{~cm}$, and medium at $80-120 \mathrm{~cm}$. Von Cossel et al. [23] also classify soils with a depth of $<35 \mathrm{~cm}$ as unsuitable, while soils with a depth of $35-80 \mathrm{~cm}$ are classified as medium, and soils with a depth of $80-120 \mathrm{~cm}$ as well suited for cultivation. The experiment in Moffat and Houston [54] shows that the survival rate of poplar plants is proportional to the soil depth, with a minimum soil depth of $20 \mathrm{~cm}$. Overall, the suitability for cultivation of poplar on soils with low rooting depth is expected to be mediocre in comparison to favored locations.

\subsubsection{Reed Canary Grass}

Reed canary grass achieves dry matter biomass yields of $5-13 \mathrm{Mg} \mathrm{ha}^{-1}$ under favorable conditions $[49,55,56]$. For example, reed canary grass achieved an average dry matter yield of $8 \mathrm{Mg} \mathrm{ha}^{-1}$ (yields of 3.9-13.8 $\mathrm{Mg} \mathrm{ha}^{-1}$ were measured) on four different favored sites in the Czech Republic from the second to the sixth year of cultivation [57].

One study from Carlow (Ireland) was found, where reed canary grass was grown under LRD conditions (Tables 1 and 2). This site has a shallow soil with a high proportion of gravel and sand with poor water retention capacity and therefore fulfils the requirements of LRD, UST-S, and UST_ST [35]. The location factors UST-S and UST_ST each have a 
negative synergy with LRD [48]. A high stone content also reduces the effective rooting volume. Sand increases the effect of the low water storage capacity of a soil with LRD [48]. The yield of the Carlow site is comparable to that of the favored sites [49]. Therefore, reed canary grass has a good suitability for cultivation on sites with LRD. Due to the negative synergies described above at this location, it can be assumed that higher yields can be achieved at locations with good soil and exclusively LRD than at the Carlow site. This contradicts Von Cossel et al. [23] and Ramirez-Almeyda et al. [5], who indicated a low suitability of reed canary grass for cultivation on sites with a soil depth of $35-80 \mathrm{~cm}$ or $40-80 \mathrm{~cm}$.

\subsection{Presumptions on Crops Where No Studies Were Found}

For seven of the preselected herbaceous and woody industrial crops, no literature on biomass yield performance on shallow soil was found. The following sections provide a brief overview of the expected suitability of these herbaceous and woody industrial crops for LRD conditions based on topic-related literature.

\subsubsection{Camelina}

In a field study (winter camelina in Morris, Minnesota, on a clay soil), it was found that camelina has a rather compact root system: $82 \%$ of the root density was located in the upper $30 \mathrm{~cm}$ of the soil, $12 \%$ in 30-60 $\mathrm{cm}$, and only about $6 \%$ in $60-100 \mathrm{~cm}$ soil depth [58]. This supports the statement in Von Cossel et al. [23] that camelina can be grown well on shallow soil below $35 \mathrm{~cm}$ and very well in soil over $35 \mathrm{~cm}$ depth. Although camelina roots are mainly found in the upper soil layers, they can grow in dry areas at depths of up to $140 \mathrm{~cm}$ to reach water [59]. However, whether or not camelina can be grown well under low rooting depth conditions is not yet proven by field trial results.

\subsubsection{Cardoon}

Following Von Cossel et al. [23], cardoon is unsuitable for cultivation under low rooting depth conditions and is only slightly suitable for soils with a depth of $35-80 \mathrm{~cm}$. This matches the specification in Gominho et al. [60] that a soil depth of $50-150 \mathrm{~cm}$ is required for the cultivation of cardoon. Cardoon builds up a deep root system, which can reach a depth of more than $5 \mathrm{~m}$ [61]. This suggests that soil depth is an important factor influencing the growth and thus the yield of cardoon [62]. Cardoon is therefore deemed unsuitable for cultivation on sites with LRD.

\subsubsection{Crambe}

For the agricultural marginality constraint LRD, no literature was found that meets the threshold values ( $<50 \mathrm{~cm}$ for flat and very flat soils) described. After a classification by Von Cossel et al. [23], crambe has good suitability for cultivation on sites with a root depth of less than $35 \mathrm{~cm}$ and a very good cultivation suitability on soils with a rooting depth greater than $35 \mathrm{~cm}$. However, this is not yet proven by field trial results. In a three-year trial with minirhizotrons, an average depth of $58 \mathrm{~cm}$ and a maximum depth of $118 \mathrm{~cm}$ of the crambe roots were determined $[63,64]$.

\subsubsection{Cup Plant}

Cup plant has a deep and extensive root system $[47,65]$. At the Braunschweig site, the maximum root depth was $80-240 \mathrm{~cm}[66,67]$. These data suggest that cup plant cannot grow well on sites with LRD and therefore has a low suitability for cultivation on shallow soils.

\subsubsection{Sorghum}

After a classification by Von Cossel et al. [23] sorghum is unsuitable for growing in locations with a root depth of less than $35 \mathrm{~cm}$, medium at a depth of $35-80 \mathrm{~cm}$, and good at $80-120 \mathrm{~cm}$. Sorghum forms a deep root system $[68,69]$, preferably in soils with a depth of 
at least $1 \mathrm{~m}$ [68]. This suggests that high yields cannot be achieved on sites with LRD and that sorghum therefore has a low suitability for cultivation.

\subsubsection{Switchgrass}

Switchgrass is unsuitable for cultivation on sites with a soil depth of less than $35 \mathrm{~cm}$, medium for soils with a depth of 35-80 cm, and good for soils with a depth of 80-120 cm. Ramirez-Almeyda et al. [5] classify the suitability of switchgrass for cultivation at different soil depths as follows: unsuitable below $40 \mathrm{~cm}, 40-80 \mathrm{~cm}$ low, and $80-120 \mathrm{~cm}$ medium. Switchgrass has a deep root system that can reach a soil depth of $3 \mathrm{~m}[70,71]$. At the Mason site, switchgrass rooted to an average depth of $81 \mathrm{~cm}$ [72]. The information provided here indicates that switchgrass cannot be grown on sites with a LRD. In addition, Parenti et al. [13] assessed sites with these characteristics as unsuitable for the cultivation of switchgrass.

\subsubsection{Willow}

The experiments conducted by Moffat and Houston [54] show that more willows survive at increased soil depths and that none can grow at a soil depth of only $20 \mathrm{~cm}$. Von Cossel et al. [23] classify the suitability of willow for cultivation as follows: low for soils with a depth of less than $35 \mathrm{~cm}$, good with $35-80 \mathrm{~cm}$ depth, and very suitable with $80-120 \mathrm{~cm}$ depth. According to Ramirez-Almeyda [5], soils with a depth of less than $40 \mathrm{~cm}$ are classified as unsuitable for growing willow, soils with a depth of $40-80 \mathrm{~cm}$ as shallow, and soils with a depth of $80-120 \mathrm{~cm}$ as moderately suitable. Since willow has a deep fine root system [50] it probably has only a limited suitability for cultivation in locations with LRD.

\subsection{Recommendations for Cultivation of Herbaceous and Woody Industrial Crops under LRD Conditions}

Following the approach by Ramirez-Almeyda et al. [5], herbaceous and woody industrial crops whose suitability for cultivation on sites with a certain marginality is rated as good or very good may be recommended for cultivation. Good and very good suitability for cultivation means that the biomass yields are comparable or even better than under favorable growth conditions. After a thorough literature search, it was found that this seems to apply only to a few herbaceous and woody industrial crops, such as reed canary grass, camelina, and crambe (Figure 3). This assumption could also only be confirmed for reed canary grass by field trial data, where an expected yield level of $13-15 \mathrm{Mg} \mathrm{ha}^{-1}$ was found. For camelina and crambe, it remains open whether or not the assumptions derived from the related literature can be confirmed by future field trial data. For all other herbaceous and woody industrial crops, either no field trial data were available or the suitability value was less than three (Figure 3).

This review article has thus shown that there are large gaps in knowledge about the best possible use of regions where agricultural land is marginal for LRD. Much more research is needed on the suitability of known herbaceous and woody industrial crops for LRD conditions in order to make the best use of such sites for biomass production in terms of more social-ecologically sustainable agriculture [73,74]. Certainly, this need does not exist if a site is allowed to lose arable status, because reforestation with coldinsensitive woody crops will then be the best solution. If arable status is to remain, however, there is a need for adapted herbaceous and woody industrial crops and the associated resource-conserving and environmentally friendly cultivation methods. 


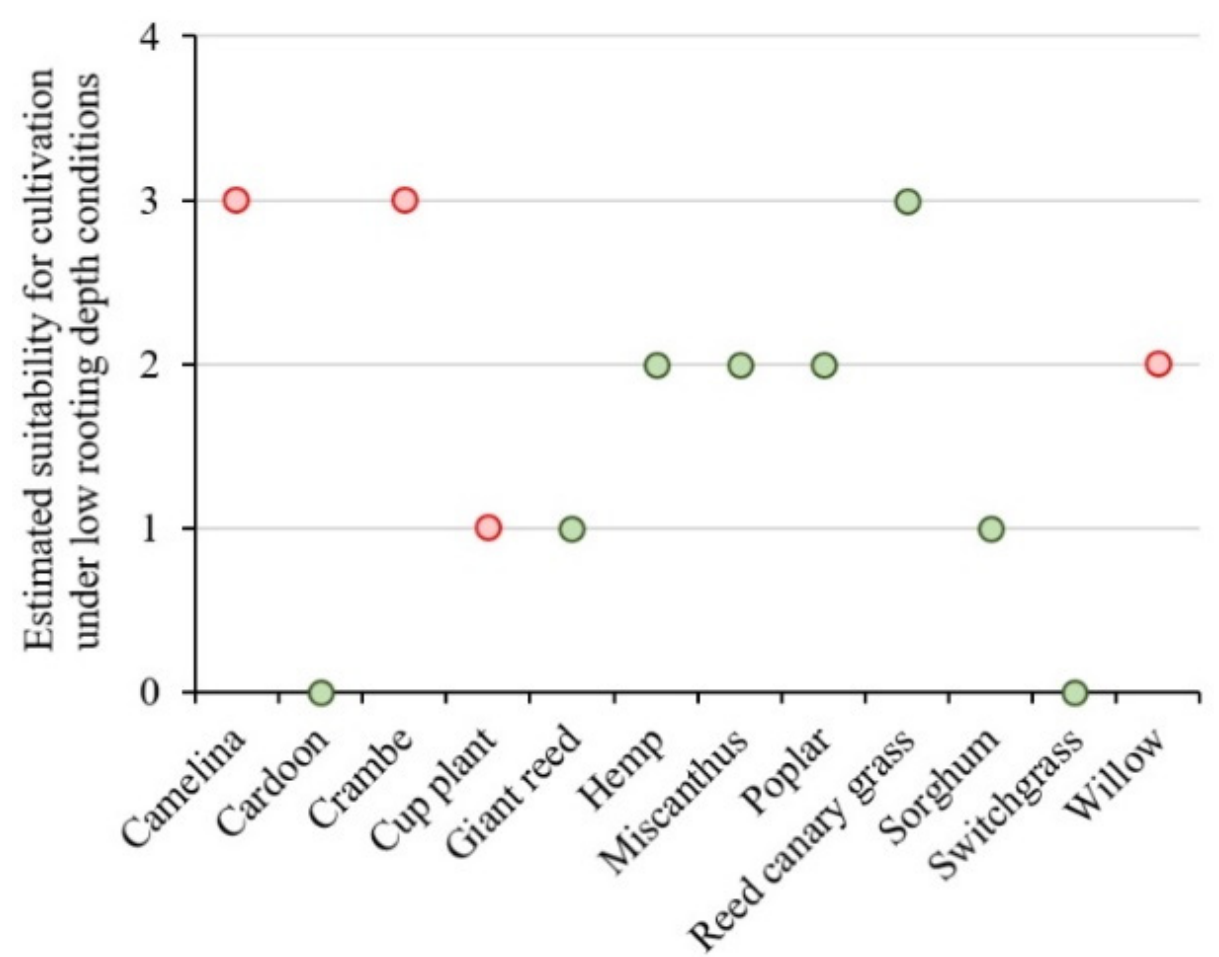

Figure 3. Overview of estimated suitability for cultivation of the preselected herbaceous and woody industrial crops under low rooting depth conditions ( $\leq 35 \mathrm{~cm}$ soil depth). Green dots denote suitability values based on field trial data; red dots denote for suitability values based on associated literature and assumptions by the authors, because no field trial data were available.

Moreover, in light of climate change, regions where drought conditions are expected to increase, for example, from Spain to Central Europe [74,75], could further expand LRD limitation due to negative combined effects [48]. These dynamics should also be considered in field research on the use of LRD sites by herbaceous and woody industrial crops, which will be a major crop science challenge. A network of experimental stations, such as the ECOFE network, could be helpful, as they can detect changes in genotype-environment interaction with a very high breeding efficiency [76]. However, in addition to the further development of cultivable herbaceous and woody industrial crops, the ongoing adaptation of logistics and the processing industry is likely to be a far greater challenge if it is not yet even known which crop species will be grown in a particular region in ten or twenty years' time.

Author Contributions: Conceptualization, J.R., P.H., and M.v.C.; methodology, J.R. and M.v.C.; investigation, J.R.; resources, J.R.; data curation, J.R.; writing—original draft preparation, J.R., P.H., and M.v.C.; writing—review and editing, P.H. and M.v.C.; visualization, M.v.C.; supervision, M.v.C.; project administration, M.v.C.; funding acquisition, M.v.C. All authors have read and agreed to the published version of the manuscript.

Funding: This research received funding from the European Union's Horizon 2020 research and innovation program under grant agreement No. 727698, the Federal Ministry of Education and Research (01PL16003), and University of Hohenheim. The APC was funded by the European Union's Horizon 2020 research and innovation program under grant agreement No. 727698.

Institutional Review Board Statement: Not applicable.

Informed Consent Statement: Not applicable.

Data Availability Statement: Data sets for this research are included in the references.

Acknowledgments: The authors are very grateful to Iris Lewandowski for making this work possible. 
Conflicts of Interest: The authors declare no conflict of interest. The funders had no role in the design of the study; in the collection, analyses, or interpretation of data; in the writing of the manuscript, or in the decision to publish the results.

\section{Appendix A}

Table A1. Industrial crops investigated in EU projects that were started or finished in the period from 1 January 2014 to 12 June 2019: $\mathrm{a}=$ MAGIC, $\mathrm{b}=$ PANACEA, $\mathrm{c}=$ SEEMLA, $\mathrm{d}=$ GRACE, $\mathrm{e}=$ Multihemp, $\mathrm{f}=$ FIBRA, $\mathrm{g}=\mathrm{COSMOS}, \mathrm{h}=$ MULTIBIOPRO, $\mathrm{i}=$ LIBBIO, $\mathrm{j}=$ GRASSMARGINS, $\mathrm{k}=$ OPTIMA, $\mathrm{l}=$ OPTIMISC, $\mathrm{m}=$ Becool, $\mathrm{n}=$ WATBIO, $\mathrm{o}=$ PHYSIO-POP, $\mathrm{p}=$ COMETHA, $\mathrm{q}=$ DENDROMASS 4EUROPE, $\mathrm{r}=$ SUNLIBB, $\mathrm{s}=$ FIRST2RUN, $\mathrm{t}=$ EUPOBIOREF, $\mathrm{u}=$ FORBIO, $\mathrm{v}=$ SWEET fuel, $\mathrm{w}=\mathrm{BIO} 4 \mathrm{~A}, \mathrm{x}=$ Mediopuntia.

\begin{tabular}{|c|c|c|c|c|c|c|c|c|c|c|c|c|c|c|c|c|c|c|c|c|c|c|c|c|c|}
\hline $\begin{array}{l}\text { Industrial Crop } \\
\text { (Common Name) }\end{array}$ & Sum & a & b & c & d & e & f & g & h & $\mathbf{i}$ & $\mathbf{j}$ & $\mathbf{k}$ & 1 & m & $\mathbf{n}$ & $\mathbf{o}$ & $\mathrm{p}$ & q & $\mathbf{r}$ & $\mathbf{s}$ & $\mathbf{t}$ & $\mathbf{u}$ & $\mathbf{v}$ & $\mathbf{w}$ & $\mathbf{x}$ \\
\hline Miscanthus & 12 & $x$ & $x$ & $x$ & $x$ & & & & & & $\mathrm{X}$ & $x$ & $\mathrm{X}$ & $x$ & $x$ & & & & $x$ & & $x$ & $\mathrm{X}$ & & & \\
\hline Giant reed & 9 & $x$ & $x$ & $x$ & & & & & & & & $X$ & & $x$ & $\mathrm{X}$ & & $x$ & & & & $x$ & $\mathrm{X}$ & & & \\
\hline Poplar & 7 & $x$ & $X$ & $x$ & & & & & $x$ & & & & & & $x$ & $X$ & & $\mathrm{X}$ & & & & & & & \\
\hline Hemp & 6 & $x$ & $x$ & & $X$ & $\mathrm{X}$ & $x$ & & & & & & & $X$ & & & & & & & & & & & \\
\hline Switchgrass & 6 & $\mathrm{X}$ & $X$ & $x$ & & & & & & & & $X$ & & $x$ & & & & & & & $x$ & & & & \\
\hline Camelina & 5 & $x$ & $x$ & & & & & $\mathrm{X}$ & & & & & & & & & & & & & $\mathrm{X}$ & & & $x$ & \\
\hline Cardoon & 5 & $\mathrm{X}$ & $x$ & $x$ & & & & & & & & $x$ & & & & & & & & $x$ & & & & & \\
\hline Sorghum & 5 & $X$ & $X$ & & & & & & & & & & & $X$ & & & & & & & & $x$ & $x$ & & \\
\hline Willow & 5 & $x$ & $x$ & $x$ & & & & & & & & & & & & & & & & & $x$ & $\mathrm{X}$ & & & \\
\hline Crampe & 4 & $x$ & $x$ & & & & & $x$ & & & & & & & & & & & & & $x$ & & & & \\
\hline Reed canary grass & 4 & $x$ & $x$ & $x$ & & & & & & & $x$ & & & & & & & & & & & & & & \\
\hline Black locust & 3 & $x$ & $X$ & $x$ & & & & & & & & & & & & & & & & & & & & & \\
\hline Castor & 3 & $x$ & $x$ & & & & & & & & & & & & & & & & & & $\mathrm{X}$ & & & & \\
\hline Eucalyptus & 3 & & $X$ & $x$ & & & & & & & & & & $X$ & & & & & & & & & & & \\
\hline Kenaf & 3 & & $x$ & & & & $x$ & & & & & & & $X$ & & & & & & & & & & & \\
\hline Lupin & 3 & $\mathrm{X}$ & $X$ & & & & & & & $X$ & & & & & & & & & & & & & & & \\
\hline Safflower & 3 & $\mathrm{X}$ & $x$ & & & & & & & & & & & & & & & & & & $\mathrm{x}$ & & & & \\
\hline Cup plant & 2 & & & $x$ & & & & & & & & & & & & & & & & & & $\mathrm{X}$ & & & \\
\hline Ethiopian mustard & 2 & $x$ & $x$ & & & & & & & & & & & & & & & & & & & & & & \\
\hline Flax & 2 & & $\mathrm{X}$ & & & & $x$ & & & & & & & & & & & & & & & & & & \\
\hline Sunflower & 2 & & $x$ & & & & & & & & & & & & & & & & & & & & & $\mathrm{X}$ & \\
\hline Alfa-alfa & 1 & & & & & & & & & & & & & & & & & & & & & $\mathrm{X}$ & & & \\
\hline Cocksfoot & 1 & & & & & & & & & & $x$ & & & & & & & & & & & & & & \\
\hline Columbus grass & 1 & & & $x$ & & & & & & & & & & & & & & & & & & & & & \\
\hline Common reed & 1 & & & $x$ & & & & & & & & & & & & & & & & & & & & & \\
\hline Cuphea & 1 & & & & & & & & & & & & & & & & & & & & $x$ & & & & \\
\hline Festulolium & 1 & & & & & & & & & & $x$ & & & & & & & & & & & & & & \\
\hline Giant Knotweed & 1 & & & $x$ & & & & & & & & & & & & & & & & & & & & & \\
\hline Guayule & 1 & & $x$ & & & & & & & & & & & & & & & & & & & & & & \\
\hline Indian fig opuntia & 1 & & & & & & & & & & & & & & & & & & & & & & & & $x$ \\
\hline Jatropha & 1 & & & & & & & & & & & & & & & & & & & & $x$ & & & & \\
\hline Jerusalem artichoke & 1 & & & $X$ & & & & & & & & & & & & & & & & & & & & & \\
\hline Lavender & 1 & & $x$ & & & & & & & & & & & & & & & & & & & & & & \\
\hline Lesquella & 1 & & & & & & & & & & & & & & & & & & & & $x$ & & & & \\
\hline Paulownia & 1 & & & $x$ & & & & & & & & & & & & & & & & & & & & & \\
\hline Pennycress & 1 & $x$ & & & & & & & & & & & & & & & & & & & & & & & \\
\hline Peppermint & 1 & & $x$ & & & & & & & & & & & & & & & & & & & & & & \\
\hline Pine & 1 & & & $x$ & & & & & & & & & & & & & & & & & & & & & \\
\hline Rapeseed (HEAR) & 1 & & $x$ & & & & & & & & & & & & & & & & & & & & & & \\
\hline Rosemary & 1 & & $x$ & & & & & & & & & & & & & & & & & & & & & & \\
\hline Russian dandelion & 1 & & $X$ & & & & & & & & & & & & & & & & & & & & & & \\
\hline Siberian elm & 1 & $x$ & & & & & & & & & & & & & & & & & & & & & & & \\
\hline Sugarbeet & 1 & & $x$ & & & & & & & & & & & & & & & & & & & & & & \\
\hline Sugarcane & 1 & & & & & & & & & & & & & & & & & & $x$ & & & & & & \\
\hline Tall fescue & 1 & & & & & & & & & & $x$ & & & & & & & & & & & & & & \\
\hline Tall wheat grass & 1 & $x$ & & & & & & & & & & & & & & & & & & & & & & & \\
\hline Tobacco & 1 & & & & & & & & $x$ & & & & & & & & & & & & & & & & \\
\hline Tree of heaven & 1 & & & $x$ & & & & & & & & & & & & & & & & & & & & & \\
\hline Triticale & 1 & & $x$ & & & & & & & & & & & & & & & & & & & & & & \\
\hline Virginia mallow & 1 & & & $x$ & & & & & & & & & & & & & & & & & & & & & \\
\hline Wild sugarcane & 1 & $x$ & & & & & & & & & & & & & & & & & & & & & & & \\
\hline
\end{tabular}


Table A2. Overview of the selected industrial crops, sorted alphabetically by common name (adapted from [2]).

\begin{tabular}{|c|c|c|c|c|c|c|}
\hline Botanical Name & Trivial Name & Life Cycle & $\begin{array}{c}\text { Photosynthetic } \\
\text { Pathway }\end{array}$ & Use & Projects & $\begin{array}{c}\text { Frequency of } \\
\text { Studies }\end{array}$ \\
\hline Arundo donax L. & Giant reed & Perennial & C3 & $\mathrm{L}$ & 9 & 8 \\
\hline Camelina sativa (L.) Crantz & Camelina & Annual & $\mathrm{C} 3$ & $\mathrm{O}$ & 5 & 6 \\
\hline Cannabis sativa $\mathrm{L}$. & Hemp & Annual & $\mathrm{C} 3$ & $\mathrm{~L} / \mathrm{O}$ & 6 & 10 \\
\hline Crambe abyssinica Hochst ex R.E.Fr. & Crambe & Annual & $\mathrm{C} 3$ & $\mathrm{O}$ & 4 & 3 \\
\hline Cynara cardunculus L. & Cardoon & Perennial & $\mathrm{C} 3$ & $\mathrm{~L} / \mathrm{O}$ & 5 & 5 \\
\hline Miscanthus Andersson & Miscanthus & Perennial & $\mathrm{C} 4$ & $\mathrm{~L}$ & 12 & 13 \\
\hline Panicum virgatum $\mathrm{L}$. & Switchgrass & Perennial & $\mathrm{C} 4$ & $\mathrm{~L}$ & 6 & 10 \\
\hline Phalaris arundinacea $\mathrm{L}$. & Phalaris & Perennial & $\mathrm{C} 3$ & $\mathrm{~L}$ & 4 & 6 \\
\hline Populus L. & Poplar & Perennial & $\mathrm{C} 3$ & W & 7 & 11 \\
\hline Salix $\mathrm{L}$ & Willow & Perennial & $\mathrm{C} 3$ & W & 5 & 13 \\
\hline Silphium perfoliatum L. ${ }^{\text {a }}$ & Cup plant & Perennial & $\mathrm{C} 3$ & $\mathrm{~L} / \mathrm{C}$ & 2 & 4 \\
\hline Sorghum bicolor L. Moench & Sorghum & Annual & $\mathrm{C} 4$ & $\mathrm{~L} / \mathrm{C}$ & 5 & 7 \\
\hline
\end{tabular}

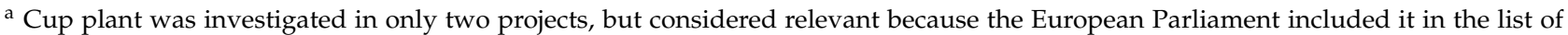
ecological priority areas in 2017 [77]; $\mathrm{L}=$ lignocellulose, $\mathrm{O}=$ oil, $\mathrm{C}=$ carbohydrates, $\mathrm{W}=$ wood.

Table A3. Overview of key agronomical data of the field trials conducted in the references identified in the literature search.

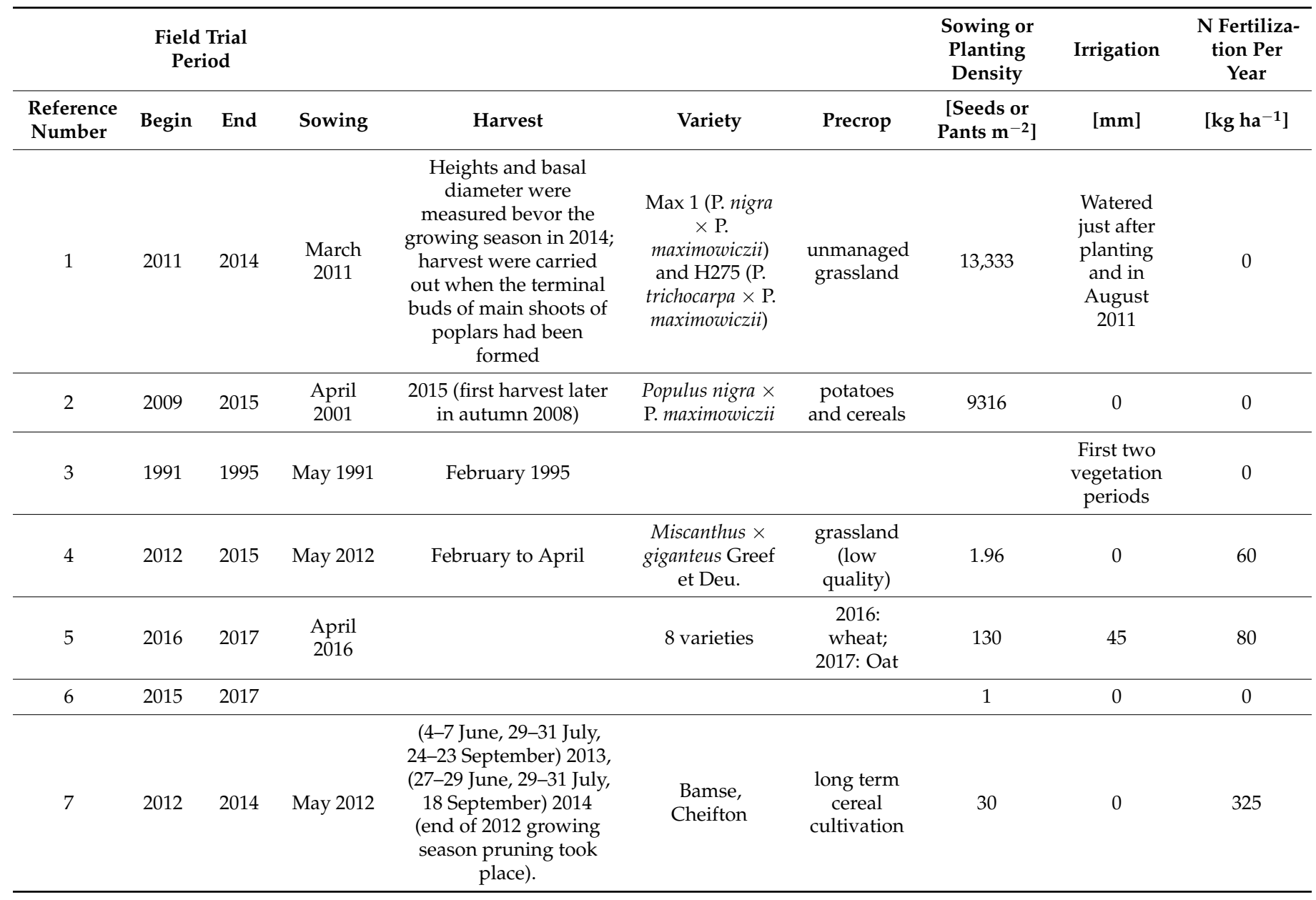


Table A4. Overview of yield relevant data from the field trials of the studies identified in the literature search.

\begin{tabular}{|c|c|c|c|c|c|c|c|c|}
\hline & & & & $\begin{array}{l}\text { Aboveground } \\
\text { Biomass Dry } \\
\text { Matter Yield }\end{array}$ & $\begin{array}{l}\text { Grain } \\
\text { Yield }\end{array}$ & $\begin{array}{l}\text { Stem Dry } \\
\text { Matter }\end{array}$ & Oil Yield & $\begin{array}{c}\text { Thousand } \\
\text { Kernel } \\
\text { Weight }\end{array}$ \\
\hline $\begin{array}{l}\text { Reference } \\
\text { Number }\end{array}$ & $\begin{array}{c}\text { Number of } \\
\text { Vegetation } \\
\text { Periods or } \\
\text { Number of } \\
\text { Cuts }\end{array}$ & $\begin{array}{l}\text { Year of } \\
\text { Cultiva- } \\
\text { tion }\end{array}$ & $\begin{array}{c}\text { Age of the } \\
\text { Tree }\end{array}$ & {$\left[\mathrm{Mg} \mathrm{ha}^{-1}\right]$} & $\begin{array}{c}{[\mathrm{Mg}} \\
\left.\mathrm{ha}^{-1}\right]\end{array}$ & {$\left[\mathrm{Mg} \mathrm{ha}^{-1}\right]$} & [L ha $\left.{ }^{-1}\right]$ & {$[g]$} \\
\hline 1 & 1 & & 3 & 0.1 & & 0.17 & & \\
\hline 2 & 1 & & 7 & 11.7 & & & & \\
\hline 3 & & 4 & & 8.9 & & & & \\
\hline 4 & & 4 & & 16.0 & & & & \\
\hline 5 & 2 & & & & 0.55 & 6.1 & 110 & 7.6 \\
\hline 6 & $2-3$ & & & 8.3 & & & & \\
\hline 7 & $2-3$ & & & 13 & & & & \\
\hline
\end{tabular}

\section{References}

1. Gerwin, W.; Repmann, F.; Galatsidas, S.; Vlachaki, D.; Gounaris, N.; Baumgarten, W.; Volkmann, C.; Keramitzis, D.; Kiourtsis, F.; Freese, D. Assessment and Quantification of Marginal Lands for Biomass Production in Europe Using Soil-Quality Indicators. Soil 2018, 4, 267-290. [CrossRef]

2. von Cossel, M.; Lewandowski, I.; Elbersen, B.; Staritsky, I.; Van Eupen, M.; Iqbal, Y.; Mantel, S.; Scordia, D.; Testa, G.; Cosentino, S.L.; et al. Marginal Agricultural Land Low-Input Systems for Biomass Production. Energies 2019, 12, 3123. [CrossRef]

3. Elbersen, B.; Van Eupen, M.; Alexopoulou, E.; Bai, Z.; Boogaard, H.; Carrasco, J.E.; Ceccarelli, T.; Ciria Ramos, C.; Ciria, P.; Cosentino, S.L.; et al. Mapping Marginal Land Potentially Available for Industrial Crops in Europe. In Proceedings of the European Biomass Conference and Exhibition Proceedings 26thEUBCE, Copenhagehn, Denmark, 14-18 May 2018. [CrossRef]

4. Elbersen, B.; Hart, K.; Koper, M.; van Eupen, M.; Keenleyside, C.; Verzandvoort, S.; Kort, K.; Cormont, A.; Giadrossi, A.; Baldock, D. Analysis of Actual Land Availability in the EU Trends in Unused, Abandoned and Degraded (Non-)Agricultural Land and Use for Energy and Other Non-Food Crops; Wageningen Environmental Research: Wageningen, The Netherlands, 2020.

5. Ramirez-Almeyda, J.; Elbersen, B.; Monti, A.; Staritsky, I.; Panoutsou, C.; Alexopoulou, E.; Schrijver, R.; Elbersen, W. Assessing the Potentials for Nonfood Crops. In Modeling and Optimization of Biomass Supply Chains; Panoutsou, C., Ed.; Academic Press: Cambridge, MA, USA, 2017; Chapter 9; pp. 219-251. ISBN 978-0-12-812303-4.

6. Dahmen, N.; Lewandowski, I.; Zibek, S.; Weidtmann, A. Integrated Lignocellulosic Value Chains in a Growing Bioeconomy: Status Quo and Perspectives. GCB Bioenergy 2019, 11, 107-117. [CrossRef]

7. Lange, L.; Connor, K.O.; Arason, S.; Bundgård-Jørgensen, U.; Canalis, A.; Carrez, D.; Gallagher, J.; Gøtke, N.; Huyghe, C.; Jarry, B.; et al. Developing a Sustainable and Circular Bio-Based Economy in EU: By Partnering Across Sectors, Upscaling and Using New Knowledge Faster, and For the Benefit of Climate, Environment \& Biodiversity, and People \& Business. Front. Bioeng. Biotechnol. 2021, 8. [CrossRef]

8. Clark, L.J.; Whalley, W.R.; Barraclough, P.B. How Do Roots Penetrate Strong Soil? Plant Soil 2003, 255, 93-104. [CrossRef]

9. Place, G.; Bowman, D.; Burton, M.; Rufty, T. Root Penetration through a High Bulk Density Soil Layer: Differential Response of a Crop and Weed Species. Plant Soil 2008, 307, 179-190. [CrossRef]

10. Schweiger, P.; Petrasek, R.; Ableidinger, C.; Hartl, W. Tiefenverteilung von Wurzeln bei Winterweizen. In Beiträge zur 10. Wissenschaftstagung Ökologischer Landbau: Zürich, 11-13 Februar 2009; Werte-Wege-Wirkungen: Biolandbau im Spannungsfeld zwischen Ernährungssicherung, Markt und Klimawandel; Mayer, J., Alföldi, T., Leiber, F., Dubois, D., Fried, P., Heckendorn, F., Hillmann, E., Klocke, P., Lüscher, A., Riedel, S., et al., Eds.; Köster: Berlin, Germany, 2009; ISBN 978-3-03736-033-0.

11. Rossiter, D.; Schulte, R.; van Velthuizen, H.; Le-Bas, C.; Nachtergaele, F.; Jones, R.; van Orshoven, J. Updated Common Bio-Physical Criteria to Define Natural Constraints for Agriculture in Europe; Terres, J., Toth, T., Van Orshoven, J., Eds.; EUR, Scientific and Technical Research Series; Publications Office: Luxembourg, 2014; Volume 26638, ISBN 92-79-38190-3.

12. Kirkegaard, J.A.; Lilley, J.M. Root Penetration Rate-A Benchmark to Identify Soil and Plant Limitations to Rooting Depth in Wheat. Aust. J. Exp. Agric. 2007, 47, 590. [CrossRef]

13. Parenti, A.; Lambertini, C.; Monti, A. Areas with Natural Constraints to Agriculture: Possibilities and Limitations for The Cultivation of Switchgrass (Panicum Virgatum L.) and Giant Reed (Arundo Donax L.) in Europe. In Land Allocation for Biomass Crops: Challenges and Opportunities with Changing Land Use; Li, R., Monti, A., Eds.; Springer International Publishing: Cham, Switzerland, 2018; pp. 39-63. ISBN 978-3-319-74536-7.

14. Mueller, L.; Schindler, U.; Behrendt, A.; Eulenstein, F.; Dannowski, R.; Schlindwein, S.L.; Shepherd, T.G.; Smolentseva, E.; Rogasik, J. The Muencheberg Soil Quality Rating (SQR): Field Manual for Detecting and Assessing Properties and Limitations of Soils for Cropping and Grazing; Leibniz-Centre for Agricultural Landscape Research (ZALF) e. V.: Muencheberg, Germany, 2007. 
15. Panoutsou, C.; Singh, A. A Value Chain Approach to Improve Biomass Policy Formation. GCB Bioenergy 2020, $12,464-475$. [CrossRef]

16. Fernando, A.L.; Rettenmaier, N.; Soldatos, P.; Panoutsou, C. Sustainability of Perennial Crops Production for Bioenergy and Bioproducts. In Perennial Grasses for Bioenergy and Bioproducts; Alexopoulou, E., Ed.; Academic Press: Cambridge, MA, USA, 2018; pp. 245-283. ISBN 978-0-12-812900-5.

17. Ferreira, J.A.; Brancoli, P.; Agnihotri, S.; Bolton, K.; Taherzadeh, M.J. A Review of Integration Strategies of Lignocelluloses and Other Wastes in 1st Generation Bioethanol Processes. Process Biochem. 2018, 75, 173-186. [CrossRef]

18. Ubando, A.T.; Felix, C.B.; Chen, W.-H. Biorefineries in Circular Bioeconomy: A Comprehensive Review. Bioresour. Technol. 2020, 299, 122585. [CrossRef]

19. Vogelpohl, T. Transnational Sustainability Certification for the Bioeconomy? Patterns and Discourse Coalitions of Resistance and Alternatives in Biomass Exporting Regions. Energy Sustain. Soc. 2021, 11, 3. [CrossRef]

20. Baum, G. Betriebswirtschaftliche Betrachtung der Wildpflanzennutzung für Biogasbetriebe 2019. Available online: https: //baden-wuerttemberg.nabu.de/natur-und-landschaft/landwirtschaft/biogas/index.html (accessed on 25 June 2021).

21. Winkler, B.; Mangold, A.; Von Cossel, M.; Clifton-Brown, J.; Pogrzeba, M.; Lewandowski, I.; Iqbal, Y.; Kiesel, A. Implementing Miscanthus into Farming Systems: A Review of Agronomic Practices, Capital and Labour Demand. Renew. Sustain. Energy Rev. 2020, 132, 110053. [CrossRef]

22. Hassan, S.S.; Williams, G.A.; Jaiswal, A.K. Moving towards the Second Generation of Lignocellulosic Biorefineries in the EU: Drivers, Challenges, and Opportunities. Renew. Sustain. Energy Rev. 2019, 101, 590-599. [CrossRef]

23. Von Cossel, M.; Iqbal, Y.; Scordia, D.; Cosentino, S.L.; Elbersen, B.; Staritsky, I.; Van Eupen, M.; Mantel, S.; Prysiazhniuk, O.; Maliarenko, O.; et al. Low-Input Agricultural Practices for Industrial Crops on Marginal Land; University of Hohenheim: Stuttgart, Germany, 2018.

24. Haberzettl, J.; Hilgert, P.; Von Cossel, M. A Critical Assessment of Lignocellulosic Biomass Yield Modeling and the Bioenergy Potential from Marginal Land-A Review. Agron. Sustain. Dev. (under review).

25. BMEL. Agrarexporte Verstehen-Fakten Und Hintergründe; BMEL: Berlin, Germany, 2018.

26. UBA, (Umweltbundesamt). Toward Ecofriendly Farming. Available online: https://www.umweltbundesamt.de/en/topics/soilagriculture/toward-ecofriendly-farming (accessed on 20 August 2020).

27. European Commission CORDIS EU Research Results. Available online: https://cordis.europa.eu/projects/en (accessed on 25 June 2021).

28. Elsevier How Can I Best Use the Advanced Search? Available online: https://service.elsevier.com/app/answers/detail/a_id/11 365/c/10546/supporthub/scopus / (accessed on 20 August 2020).

29. Euring, D.; Ayegbeni, S.; Jansen, M.; Tu, J.; Gomes Da Silva, C.; Polle, A. Growth Performance and Nitrogen Use Efficiency of Two Populus Hybrid Clones (P. Nigra $\times$ P. Maximowiczii and P. Trichocarpa $\times$ P. Maximowiczii) in Relation to Soil Depth in a Young Plantation. iForest Biogeosci. For. 2016, 9, 847. [CrossRef]

30. Orság, M.; Fischer, M.; Tripathi, A.M.; Žalud, Z.; Trnka, M. Sensitivity of Short Rotation Poplar Coppice Biomass Productivity to the Throughfall Reduction-Estimating Future Drought Impacts. Biomass Bioenergy 2018, 109, 182-189. [CrossRef]

31. Lewandowski, I.; Kicherer, A. Combustion Quality of Biomass: Practical Relevance and Experiments to Modify the Biomass Quality of Miscanthus x Giganteus. Eur. J. Agron. 1997, 6, 163-177. [CrossRef]

32. Kalinina, O.; Nunn, C.; Sanderson, R.; Hastings, A.F.S.; van der Weijde, T.; Özgüven, M.; Tarakanov, I.; Schüle, H.; Trindade, L.M.; Dolstra, O.; et al. Extending Miscanthus Cultivation with Novel Germplasm at Six Contrasting Sites. Front. Plant Sci. 2017, 8. [CrossRef] [PubMed]

33. Baldini, M.; Ferfuia, C.; Piani, B.; Sepulcri, A.; Dorigo, G.; Zuliani, F.; Danuso, F.; Cattivello, C. The Performance and Potentiality of Monoecious Hemp (Cannabis Sativa L.) Cultivars as a Multipurpose Crop. Agronomy 2018, 8, 162. [CrossRef]

34. Ozdemir, S.; Yetilmezsoy, K.; Nuhoglu, N.N.; Dede, O.H.; Turp, S.M. Effects of Poultry Abattoir Sludge Amendment on Feedstock Composition, Energy Content, and Combustion Emissions of Giant Reed (Arundo Donax L.). J. King Saud Univ. Sci. 2020, 32, 149-155. [CrossRef]

35. Meehan, P.; Burke, B.; Doyle, D.; Barth, S.; Finnan, J. Exploring the Potential of Grass Feedstock from Marginal Land in Ireland: Does Marginal Mean Lower Yield? Biomass Bioenergy 2017, 107, 361-369. [CrossRef]

36. Altieri, M.A.; Nicholls, C.I.; Montalba, R. Technological Approaches to Sustainable Agriculture at a Crossroads: An Agroecological Perspective. Sustainability 2017, 9, 349. [CrossRef]

37. Laurent, A.; Pelzer, E.; Loyce, C.; Makowski, D. Ranking Yields of Energy Crops: A Meta-Analysis Using Direct and Indirect Comparisons. Renew. Sustain. Energy Rev. 2015, 46, 41-50. [CrossRef]

38. Scordia, D.; Testa, G.; Cosentino, S.L. Perennial Grasses as Lignocellulosic Feedstock for Second-Generation Bioethanol Production in Mediterranean Environment. Ital. J. Agronomy 2014, 9, 84. [CrossRef]

39. Angelini, L.G.; Ceccarini, L.; Di Nassi o Nasso, N.; Bonari, E. Comparison of Arundo Donax L. and Miscanthus x Giganteus in a Long-Term Field Experiment in Central Italy: Analysis of Productive Characteristics and Energy Balance. Biomass Bioenergy 2009, 33, 635-643. [CrossRef]

40. Pilu, R.; Manca, A.; Landoni, M. Arundo Donax as an Energy Crop: Pros and Cons of the Utilization of This Perennial Plant. Maydica 2013, 58, 54-59. 
41. Bócsa, I.; Karus, M.; Lohmeyer, D. Der Hanfanbau; Vollst. überarb. und erg. 2. Aufl.; Landwirtschaftsverl.: Münster-Hiltrup, Germany, 2000; ISBN 3-7843-3066-5.

42. Struik, P.C.; Amaducci, S.; Bullard, M.J.; Stutterheim, N.C.; Venturi, G.; Cromack, H.T.H. Agronomy of Fibre Hemp (Cannabis Sativa L.) in Europe. Ind. Crop. Prod. 2000, 11, 107-118. [CrossRef]

43. Manevski, K.; Lærke, P.E.; Jiao, X.; Santhome, S.; Jørgensen, U. Biomass Productivity and Radiation Utilisation of Innovative Cropping Systems for Biorefinery. Agric. For. Meteorol. 2017, 233, 250-264. [CrossRef]

44. Amaducci, S.; Zatta, A.; Raffanini, M.; Venturi, G. Characterisation of Hemp (Cannabis Sativa L.) Roots under Different Growing Conditions. Plant Soil 2008, 313, 227. [CrossRef]

45. Lewandowski, I.; CLIFTON-BROWN, J.C.; Scurlock, J.M.O.; Huisman, W. Miscanthus: European Experience with a Novel Energy Crop. Biomass Bioenergy 2000, 19, 209-227. [CrossRef]

46. Amaducci, S.; Facciotto, G.; Bergante, S.; Perego, A.; Serra, P.; Ferrarini, A.; Chimento, C. Biomass Production and Energy Balance of Herbaceous and Woody Crops on Marginal Soils in the Po Valley. GCB Bioenergy 2017, 9, 31-45. [CrossRef]

47. Bufe, C.; Korevaar, H. Evaluation of Additional Crops for Dutch List of Ecological Focus Area; Report/WPR; Wageningen Research Foundation (WR) Business Unit Agrosystems Research: Lelystad, The Netherlands, 2018; Volume 793.

48. Confalonieri, R.; Jones, B.; Van Diepen, K.; Van Orshoven, J. Scientific Contribution on Combining Biophysical Criteria Underpinning the Delineation of Agricultural Areas Affected by Specific Constraints: Methodology and Factsheets for Plausible Criteria Combinations; Terres, J., Hagyo, A., Wania, A., Eds.; Publications Office: Luxembourg, 2014.

49. Lewandowski, I.; Scurlock, J.M.O.; Lindvall, E.; Christou, M. The Development and Current Status of Perennial Rhizomatous Grasses as Energy Crops in the US and Europe. Biomass Bioenergy 2003, 25, 335-361. [CrossRef]

50. Ferrarini, A.; Fornasier, F.; Serra, P.; Ferrari, F.; Trevisan, M.; Amaducci, S. Impacts of Willow and Miscanthus Bioenergy Buffers on Biogeochemical N Removal Processes along the Soil-Groundwater Continuum. GCB Bioenergy 2017, 9, 246-261. [CrossRef]

51. Panacea. Scientific Papers and Training Materials-Panacea. Summary Factsheet Miscanthus; Agricultural University of Athens: Athens, Greece, 2020.

52. Berendonk, C.; Dahlhoff, A.; Dickeduisberg, M.; Dissemond, A.; Erhardt, N.; Gruber, W.; Hartmann, H.-B.; Holz, J.; Günter, J.; Kasten, P.; et al. Nachwachsende Rohstoffe Vom Acker; Landwirtschaftskammer Nordrhein-Westfalen: Münster, Germnay, 2012.

53. Paris, P.; Mareschi, L.; Sabatti, M.; Pisanelli, A.; Ecosse, A.; Nardin, F.; Scarascia-Mugnozza, G. Comparing Hybrid Populus Clones for SRF across Northern Italy after Two Biennial Rotations: Survival, Growth and Yield. Biomass Bioenergy 2011, 35, 1524-1532. [CrossRef]

54. Moffat, A.; Houston, T. Tree Establishment and Growth at Pitsea Landfill Site, Essex, U.K. Waste Manag. Res. 1991, 9, 35-46. [CrossRef]

55. Tilvikiene, V.; Kadziuliene, Z.; Dabkevicius, Z.; Venslauskas, K.; Navickas, K. Feasibility of Tall Fescue, Cocksfoot and Reed Canary Grass for Anaerobic Digestion: Analysis of Productivity and Energy Potential. Ind. Crop. Prod. 2016, 84, 87-96. [CrossRef]

56. Ust'ak, S.; Šinko, J.; Muňoz, J. Reed Canary Grass (Phalaris Arundinacea L.) as a Promising Energy Crop. J. Cent. Eur. Agric. 2019, 20, 1143-1168. [CrossRef]

57. Strašil, Z. Evaluation of Reed Canary Grass (Phalaris Arundinacea L.) Grown for Energy Use. Res. Agr. Eng. 2012, 58, 119-130. [CrossRef]

58. Gesch, R.W.; Johnson, J.M.-F. Water Use in Camelina-Soybean Dual Cropping Systems. Agron. J. 2015, 107, 1098-1104. [CrossRef]

59. Hunsaker, D.J.; French, A.N.; Clarke, T.R.; El-Shikha, D.M. Water Use, Crop Coefficients, and Irrigation Management Criteria for Camelina Production in Arid Regions. Irrig. Sci. 2011, 29, 27-43. [CrossRef]

60. Gominho, J.; Curt, M.D.; Lourenço, A.; Fernández, J.; Pereira, H. Cynara Cardunculus L. as a Biomass and Multi-Purpose Crop: A Review of 30 Years of Research. Biomass Bioenergy 2018, 109, 257-275. [CrossRef]

61. Archontoulis, S.V.; Struik, P.C.; Vos, J.; Danalatos, N.G. Phenological Growth Stages of Cynara Cardunculus: Codification and Description According to the BBCH Scale. Ann. Appl. Biol. 2010, 156, 253-270. [CrossRef]

62. Curt, M.D.; Mosquera, F.; Sanz, M.; Sánchez, J.; Sánchez, G.; Esteban, B.; Fernández, J. Effect of Land Slope on Biomass Production of Cynara Cardunculus L. In Proceedings of the 20th EU Biomass Conference and Exhibition, Milan, Italy, 18-22 June 2012; pp. 186-190.

63. Merrill, S.D.; Tanaka, D.L.; Hanson, J.D. Root Length Growth of Eight Crop Species in Haplustoll Soils. Soil Sci. Soc. Am. J. 2002, 66, 913. [CrossRef]

64. Merrill, S.D.; Tanaka, D.L.; Hanson, J.D. Comparison of Fixed-Wall and Pressurized-Wall Minirhizotrons for Fine Root Growth Measurements in Eight Crop Species. Agron. J. 2005, 97, 1367-1373. [CrossRef]

65. Favorite, J. Cup Plant; USDA NRCS National Plant Data Center: Washington, DC, USA, 2003.

66. Schittenhelm, S.; Schoo, B.; Schroetter, S. Yield physiology of biogas crops: Comparison of cup plant, maize, and lucerne-grass. J. Kult. 2016, 68, 378-384.

67. Schoo, B.; Schroetter, S.; Kage, H.; Schittenhelm, S. Root Traits of Cup Plant, Maize and Lucerne Grass Grown under Different Soil and Soil Moisture Conditions. J. Agron. Crop Sci. 2017, 203, 345-359. [CrossRef]

68. Panoutsou, C.; Singh, A. Training Materials for Agronomists and Students; Imperial College London: London, UK, 2019.

69. Zeller, F.J. Sorghum (Sorghum Bicolor L. Moench): Utilization, Genetics, Breeding. Bodenkultur 2000, 51, 71-85. 
70. Alexopoulou, E.; Monti, A.; Elbersen, H.W.; Zegada-Lizarazu, W.; Millioni, D.; Scordia, D.; Zanetti, F.; Papazoglou, E.G.; Christou, M. Switchgrass: From Production to End Use. In Perennial Grasses for Bioenergy and Bioproducts; Alexopoulou, E., Ed.; Academic Press: Cambridge, MA, USA, 2018; pp. 61-105. ISBN 978-0-12-812900-5.

71. Parrish, D.J.; Fike, J.H. The Biology and Agronomy of Switchgrass for Biofuels. Crit. Rev. Plant Sci. 2005, 24, 423-459. [CrossRef]

72. Porensky, L.M.; Davison, J.; Leger, E.A.; Miller, W.W.; Goergen, E.M.; Espeland, E.K.; Carroll-Moore, E.M. Grasses for Biofuels: A Low Water-Use Alternative for Cold Desert Agriculture? Biomass Bioenergy 2014, 66, 133-142. [CrossRef]

73. Moore, K.J.; Kling, C.L.; Raman, D.R. A Midwest USA Perspective on Von Cossel et Al.'s Prospects of Bioenergy Cropping Systems for a More Social-Ecologically Sound Bioeconomy. Agronomy 2020, 10, 1658. [CrossRef]

74. Von Cossel, M.; Wagner, M.; Lask, J.; Magenau, E.; Bauerle, A.; Von Cossel, V.; Warrach-Sagi, K.; Elbersen, B.; Staritsky, I.; Van Eupen, M.; et al. Prospects of Bioenergy Cropping Systems for a More Social-Ecologically Sound Bioeconomy. Agronomy 2019, 9, 605. [CrossRef]

75. Teuling, A.J. A Hot Future for European Droughts. Nat. Clim. Chang. 2018, 8, 364. [CrossRef]

76. Stützel, H.; Brüggemann, N.; Inzé, D. The Future of Field Trials in Europe: Establishing a Network Beyond Boundaries. Trends Plant Sci. 2016, 21, 92-95. [CrossRef] [PubMed]

77. European Commission. (EC) COMMISSION DELEGATED REGULATION (EU) 2018/1784-of 9 July 2018-Amending Delegated Regulation (EU) No 639/2014 as Regards Certain Provisions on the Greening Practices Established by Regulation (EU) No 1307/2013 of the European Parliament and of the Council. 2018, p. 4. Available online: https:/ / eur-lex.europa.eu/legal-content/ en/TXT/?uri=CELEX:32018R1784 (accessed on 25 June 2021). 